\title{
KARTINI: PERJUANGAN DAN PEMIKIRANNYA
}

\author{
Oleh: Sudrajat ${ }^{*}$
}

\begin{abstract}
Kartini was native Indonesian woman in that have consciousness gender equality. Despite as a woman's hero, Kartini has a perpective about the way how to reach for Indonesian independent. All about of the Kartini perspectives was writeen on his letters that send to his friends. Later, JH Abendanon collects Kartini's letters and published it on the title Door Duisternis Tot Licht (Out of Dark Comes Light).

This article attemp to analizes the struggle and views of Kartini. The writers recite her letters in which publishes by Agnes Symmer by the title of Letters of A Javanese Princess: Raden Adjeng Kartini. By employing critic-analytical method the writers attempt to compare this book with another.

The struggle of Kartini includes a gender equality, because she attemps to increase the degree of Indonesian woman by empowering themselves. Kartini says that Indonesian woman must be out from handcuff customs. It can be reach with education in which employee the Indonesian woman. Kartini wanted native Indonesian women have the freedom to learn and study. Kartini so has a perspective about the way that can be reach to Indonesian independent with nationalism, unity and social solidarity. The nationalism that Kartini's views, includes the universal nationalism. It means that the idea of kartini nationalism appears universal moral value: liberty, equality, solidarity, and fraternity.
\end{abstract}

Keyword: gender equality, education, nationalism.

\section{A. Pendahuluan}

Studi tentang wanita (woman study) dalam sejarah Indonesia merupakan studi yang jauh tertinggal bila dibandingkan dengan bidang ilmu sosial yang lain. Dalam hal ini sosiologi merupakan pioneer bagi pengkajian tentang studi wanita. Penelitian tentang peranan wanita dalam sektor sosial, ketenagakerjaan dan keluarga berencana merupakan tema-tema yang telah lama menjadi bahan penelitian dalam sosiologi. Namun, woman study tetap belum memperoleh kedudukan sendiri dalam ilmu-ilmu sosial di negeri ini. ${ }^{1}$ Sungguhpun demikian, akhir-akhir ini, studi tentang wanita telah menarik perhatian dari pelbagai ahli. Barangkali trend munculnya tokoh-tokoh wanita dalam tampuk kekuasaan politik

\footnotetext{
* Dosen pada Jurusan Pendidikan Sejarah FISE UNY.

${ }^{1}$ Kuntowijoyo, (2003), Metodologi Sejarah, Yogyakarta: Tiara Wacana, hlm. 113.
} 
di Asia akhir-akhir ini menjadikan-nya sebagai momentum bagi tumbuhnya minat terhadap kajian tentang wanita. Megawati Sukarno Putri (Indonesia), Gloria Macapagal Arroyo (Philipina), Shek Hazina (Bangladesh), Benazir Bhuto (Pakistan), Indira Gandhi, Sonia Gandhi (India), dan lain-lain memberikan penegasan bahwa wanita dapat tampil sebagai aktor yang memiliki kekuatan dan kemampuan untuk memimpin suatu masyarakat dan bahkan menjadi top leader bagi bangsanya.

Sebenarnya apabila kita kembali membuka lembaran sejarah nasional kita, maka kita akan dapat menjumpai tampilnya tokoh-tokoh wanita yang berperan dalam upaya meningkatkan peranan dan eksistensi bangsa ini melalui berbagai bidang. Namun karena keterbatasan sumber dan sekali lagi karena kajian tentang wanita belum mendapatkan tempat yang layak, maka belum banyak tokoh-tokoh wanita dalam sejarah Indonesia yang dikaji secara intensif dan mendalam. Kartini merupakan satu diantara sekian banyak tokoh wanita Indonesia yang telah mendapat perhatian. Hal ini karena semata-mata beliau meninggalkan pemikiranpemikiran yang dapat dirunut dari surat-suratnya yang telah dibukukan. Perjuangan dan pemikirannya tentang emansipasi wanita telah dirasakan gaungnya sejak lama.

Selain ditetapkan sebagai pahlawan nasional dengan SK Presiden RI nomer 108, 2/5/1964, tanggal lahirnya pun juga ditetapkan sebagai hari nasional. Peringatan Hari Kartini terasa sangat semarak dimana murid-murid sekolah mengenakan busana tradisional Jawa berupa kain kebaya, dan acara-acara yang lain. Namun kemeriahan peringatan Hari Kartini tidak berarti merupakan sebuah ekspresi dari pendalaman nilai-nilai perjuangan Kartini. Bahkan momentum tersebut terkadang diselipi dengan hal-hal yang tidak selaras dengan nilai-nilai perjuangan Kartini seperti kontes kecantikan, untuk kemudian pemenangnya dipilih menjadi Putri Kartini. ${ }^{2}$ Bagi pemenang tentunya kemudian memiliki kesempatan yang lebih luas untuk mendapatkan job-job yang menggiurkan, seperti menjadi model atau bintang sinetron misalnya. Bagi yang tidak cantik meskipun memiliki kemampuan intelektual yang luar biasa, jangan harap untuk dapat menjadi juara.

\footnotetext{
${ }^{2}$ Awuy, Tomy F., (1995), Wacana Tragedi dan Dekonstruksi Kebudayaan, Yogyakarta: Jentera Wacana Publika, hlm. 112.
} 
Sejarah nasional Indonesia pun masih menempatkan sejarah pergerakan perempuan dalam sebuah konstruk yang bias terhadap jender. Konstruk sejarah nasional, termasuk yang diajarkan di sekolah-sekolah mensistematisasi pergerakan perempuan yang menyumbang perubahan dan kemajuan bangsa lewat kegiatan publik. Perjuangan perempuan baru dianggap penting jika melakukan kegiatan publik yang selama ini banyak dilakukan oleh laki-laki. ${ }^{3}$ Memang harus diakui bahwa perjuangan feminisme yang berorientasi pada kesetaraan gender baru muncul pada tahun 1960-an. Gerakan tersebut baru menjadi isu dalam kaitannya dengan pembangunan pada tahun 1970-an. Munculnya LSM yang peduli dengan masalah tersebut semakin meningkatkan gaung kesetaraan gender dalam berbagai bidang kehidupan. ${ }^{4}$

Oleh karenanya harus dilakukan dekonstruksi atas penulisan sejarah nasional kita dengan menempatkan sejarah pergerakan perempuan secara proporsional. Tulisan ini akan mencoba memaknai perjuangan Kartini dengan mengungkap pikiran-pikiran Kartini sebagai kontribusi terhadap bangsa kita ini. Sebagaimana telah diungkap di atas pemaknaan terhadap Kartini sudah selayaknya ditujukan untuk memahami pikiran dan perjuangannya dan tidak lagi sekadar menampilkan kontes-kontes yang malahan cenderung melukai arti gerakan perempuan itu sendiri. Dengan memaknai perjuangan dan pemikirannya, diharapkan kita akan menyadari bahwa Kartini merupakan salah seorang dari sedikit wanita Indonesia yang memiliki perpektif jauh pada masanya. Secara kritis Kartini menyorot peran wanita Indonesia yang termargionalisasi oleh konstruk budaya. Kartini juga berpendapat bahwa cara-cara untuk mewujudkan kemerdekaan bangsa Indonesia adalah lewat persatuan, nasionalisme, pendidikan dan lain-lain. Inilah makna yang seharusnya kita tangkap dari perjuangan dan pemikiran Kartini.

\section{B. Riwayat Singkat Kartini}

Raden Ajeng Kartini merupakan sosok wanita yang dilahirkan ditengahtengah keluarga bangsawan Jawa. Ia lahir pada tanggal 21 April 1879 dan wafat

\footnotetext{
${ }^{3}$ Muttaqin, Farid., “Sejarah Gerakan Perempuan yang Bias Jender”, Kompas Edisi 28 Juni 2004.

${ }^{4}$ Fakih, Mansour, (2004), Analisis Gender \& Transformasi Sosial, Yogyakarta: Pustaka Pelajar, hlm. 160 .
} 
pada tanggal 17 September $1904 .^{5}$ Ayah Kartini bernama RMAA Sosroningrat sedangkan ibunya adalah MA Ngasirah. MA Ngasirah merupakan istri pertama namun bukan yang utama karena peraturan kolonial waktu itu mengharuskan seorang bupati beristri bangsawan. Untuk itu RMAA Sosronigrat kemudian menikah lagi dengan RA Woerjan (Moerjam). ${ }^{6}$

Perkawinan RMAA Sosoroningrat dengan MA. Ngasirah melahirkan 8 orang anak yaitu: RM Slamet Sosroningrat, P. Sosroboesono, RM Panji Sosro Kartono, RA Kartini, RA Kardinah, RM Sosro Mulyono, RA Sumatri Sosrohadi Kusumo, RM Sosrorawito. Sementara itu perkawinannya dengan RA Moerjam melahirkan 3 orang anak yaitu: RA Sulastri Hadisosro, RA Roekmini dan RA Kartinah. $^{7}$

Dalam kultur masyarakat Jawa, bangsawan memiliki kedudukan yang sangat istimewa. Ia merupakan kelompok masyarakat yang dianggap sebagai model dari kultur budayanya. Ia memberikan nilai-nilai moral dalam kehidupan masyarakat. Bangsawan juga merupakan satu-satunya kelompok yang sangat dekat dengan raja. Karena kerajaan merupakan pusat budaya maka dengan demikian bangsawan merupakan konseptor dari kultur masyarakatnya. Dari keluarga seperti inilah Kartini dilahirkan.

Keluarga Kartini merupakan kelompok bangsawan yang telah berpkiran maju. Kakeknya, Pengeran Condronegoro merupakan generasi awal dari rakyat Jawa yang menerima pendidikan Barat dan menguasai bahasa Belanda dengan sempurna. Diantara putra-putra Pangeran Condronegoro yang terkenal adalah Pangeran Ario Hadiningrat, RMAA Ario Condronegoro dan RMAA Sosroningrat. ${ }^{8}$ RMAA Condronegoro merupakan seorang sastrawan yang banyak dikenal oleh pembaca baik di Indonesia maupun di Belanda. Buku-buku yang pernah ditulisnya antara lain: Kesalahan-kesalahan dalam berkarya sastra Jawa (1865), Pengelanaan Jawa (1866), dan Kritik dan catatan atas buku karangan Veth “Java” jilid 1 (18751888). ${ }^{9}$

5 Wikipedia, www.wikipedia.org/wiki/Raden_Adjeng_Kartini. didownload tanggal 12 Februari 2007.

${ }^{6}$ Ibid.

${ }^{7}$ Sasroatmojo, Suryanto., (2005), Tragedi Kartini, Yogyakarta: Penerbit Narasi, hlm. 170.

${ }^{8}$ Ibid., hlm. 10.

${ }^{9}$ Ibid., hlm. 12. 
Putra-putri RMAA Sosroningrat pada akhirnya nanti tumbuh menjadi tokohtokoh yang memiliki kemampuan yang luar biasa serta memiliki komitmen yang sangat kuat untuk cita-cita perdamaian dan kemajuan bangsanya. P Sosroboesono yang kemudian menjadi Bupati Ngawi merupakan seorang aparat yang sangat dikenal karena kemampuannya dalam membangun balai pertukangan di daerahnya. Sementara itu RM Sosrokartono terkenal karena kemampuan intelektualnya yang berkaliber internasional. Beliau pernah menjadi koresponden majalah “Times”, “Chicago Daily News”, dan "New York Herald Tribune”. Beliau merupakan seorang tokoh yang selalu menyuarakan perdamaian di Eropa melalui konggreskonggres dan seminar di Eropa.

RMAA Sosroningrat, ayah Kartini merupakan seorang bangsawan yang berpikiran maju. Beliau memberikan pendidikan Barat kepada seluruh anakanaknya karena didorong oleh adanya kesadaran akan pentingnya ilmu pengetahuan demi kemajuan bangsa dan negaranya. Sampai usia 12 tahun, Kartini mendapat pendidikan di ELS (Europese Lagere School) dimana Kartini mendapat pelajaran Bahasa Belanda. Kartini juga banyak membaca surat kabar yang terbit di Semarang yaitu De Locomotief. Disamping itu Kartini juga sering mengirimkan tulisannya kepada majalah wanita yang terbit di Belanda yaitu De Hollandsche Lelie. Di samping membaca majalah, Kartini juga membaca buku Max Havelaar dan Surat-surat Cinta karya Multatuli, lalu De Stille Kracht karya Louis Coperus, dan sebuah roman anti perang yang berjudul Die Waffen Nieder karya Berta Von Suttner. ${ }^{10}$

Kartini merupakan salah satu dari sedikit perempuan Indonesia yang menguasai berbahasa Belanda dengan baik. Kemampuannya dalam berbahasa Belanda merupakan modal pengetahuan yang amat berharga untuk berhubungan dengan teman-temannya terutama dari Eropa. Koprespodensi Kartini dengan wanita modern dari Eropa seperti Stella Zeehandelaar, semakin membuka wawasannya khususnya tentang kemajuan wanita. Hal inilah yang mendorong Kartini untuk memajukan kaum wanita Indonesia yang saat itu berada dalam status sosial yang sangat rendah.

\footnotetext{
${ }^{10}$ Wikipedia, op. cit.
} 
Sebenarnya Kartini memiliki cita-cita untuk melajutkan sekolahnya ke Belanda. Cita-cita ini mendapat dukungan dari teman-temam Kartini di Belanda seperti Stella Zeehandelaar. Namun, sebaliknya hal ini mendapat tantangan dari ayahandanya, sehingga Kartini memendam kekecewaan yang mendalam. Kartini juga harus berhadapan dengan realitas budaya Jawa dimana dia harus mengalami masa pingitan pada umur 11 tahun dan menikah dengan laki-laki pilihan orang tuanya. Inilah tragedi yang dialami oleh Kartini, sesuatu yang sangat ditentangnya namun terpaksa diterima demi rasa hormat dan patuh kepada ayahnya.

\section{Kartini dan Perjuangan Kesetaraan Gender}

Kartini merupakan salah seorang dari sedikit perempuan Indonesia yang memperoleh pendidikan Barat. Meskipun hanya memperoleh pendidikan tingkat Elementary School yaitu Europesche Lagere School, namun Kartini telah dapat menguasai bahasa Belanda sehingga ia memiliki modal pengetahuan yang cukup untuk berhubungan dengan dunia modern. Komunikasinya dengan teman-temannya di Eropa dilakukan lewat surat-menyurat dalam bahasa Belanda. Kamampuannya yang luar biasa dari seorang Kartini dalam berbahasa Belanda memang diakui oleh banyak pihak. Ia sanggup membuat kalimat-kalimat yang sangat baik dan menarik perhatian para sastrawan. Oleh karenanya tidak berlebihan bila kemudian Suryanto Sastroatmodjo menempatkan Kartini sebagai seorang penyair prosalirik, dimana surat-surat Kartini merupakan sebuah kesatuan cerita yang memiliki nilai sastra yang tinggi. ${ }^{11}$

Lewat surat-suratnya tersebut Kartini banyak mengungkapkan keadaan kaumnya dan juga harapan-harapannya tentang upaya meningkatkan derajat kaum wanita Indonesia. Kartini mengungkapkan pemikiran-pemikirannya tentang nasionalisme dan perjuangan untuk meningkatkan derajat bangsa Indonesia. Suratsurat Kartini kemudian dikumpulkan dan dibukukan oleh JH Abendanon, dengan judul Door Duisternis tot Licht. Buku ini telah diterjemahkan ke dalam bahasa Indonesia oleh Armin Pane dengan judul Habis Gelap Terbitlah Terang. Sementara itu Agnes Louise Symmers men-terjemahkannya ke dalam bahasa Inggris dengan judul Letters of A Javanese Princess.

\footnotetext{
${ }^{11}$ Sastroatmojo, Suryanto, op. cit., hlm. 60.
} 
Sebagian besar surat-surat Kartini mengisahkan tentang keadaan kaum wanita di Indonesia yang secara umum masih sangat tertinggal. Hal ini disebabkan oleh aturan adat dan budaya Jawa yang menempatkan wanita dalam posisi yang inferior bila dibandingkan dengan pria. Dalam konstruk budaya Jawa peranan wanita hanya berkisar pada tiga kawasan yaitu di sumur (mencuci dan bersihbersih), di dapur (memasak) dan di kasur (melayani suami). Atau dengan perkataan lain peranan wanita adalah macak, masak dan manak. Lebih jauh gambaran wanita Jawa adalah sebagai konco wingking, yaitu sebagai pembantu yang melayani suami untuk urusan belakang. Karena peranannya yang marjinal tersebut maka wanita tidak perlu mendapatkan pendidikan yang tinggi. Keadaan wanita Indonesia, khususnya di Jawa pada zaman tersebut juga dapat dilihat dari ungkapaan B.H. Lans, seorang guru wanita berkebangsaan Belanda yang bertugas di Sunda. Beliau menulis,” Waktu saya mulai bekerja disini, hampir tidak ada atau sedikit sekali gadis-gadis yang pergi ke sekolah ... Semua kebebasan yang dimiliki gadis-gadis hilang lenyap pada usia menjelang kawin, yaitu pada usia sepuluh atau dua belas tahun”. 12

Dalam suratnya kepada Stella Zeehandelaar tanggal 25 Mei 1899, Kartini mengungkapkan keadaan dirinya dan wanita-wanita pada umumnya. Kartini menulis, “... we girls, so far as education goes, fettered by our ancient traditions and conventions, have profited but little by these advantage. It was a great crime against the customs of our land that we should be taught at all, and especially that we should leave the house every day to go to school. For the custom of our country forbade girls in the strongest manner ever to go to outside of the house...". 13 Dengan korespodensinya dengan Stella Zeehandelaar, Kartini berharap mendapat pertolongan darinya. Kartini juga mengungkapkan bahwa dirinya ingin menjadi wanita yang maju seperti wanita Eropa. ${ }^{14}$

Kartini sadar bahwa keinginannya untuk maju hanya dapat ditempuh melalui pendidikan yang lebih tinggi dari ia peroleh saat itu. Kartini mengajukan permohonan kepada ayahnya untuk melanjutkan sekolah HBS di Semarang, namun

\footnotetext{
12 Poesponegoro, Marwati Djoened \& Notosusanto, Nugoho., (1993), Sejarah Nasional Indonesia V, Jakarta: PT Balai Pustaka, hlm. 238.

${ }^{13}$ Geertz, Hildred (ed.) (1964), Letters of A Javanese Princess: Raden Adjeng Kartini,.(ab. Agnes Louise Symmers) New York: Norton Company. hlm. 32.

${ }^{14}$ Ibid., hlm. 31.
} 
ditolak mentah-mentah. Akan tetapi ketika Kartini menyatakan ingin melanjutkan studi ke Eropa ayahnya diam dan tidak memberikan reaksi apa-apa. Kartini berkesimpulan bahwa ayahnya tidak keberatan kalau ia melanjutkan studinya ke Eropa. Kartini mengirim surat kepada pemerintah agar ia diberi bantuan untuk melanjutkan studi ke Eropa. Balasan dari pemerintah Belanda datang dua tahun kemudian, tepatnya pada tanggal 23 Juli 1903. Pada dasarnya pemerintah Belanda menyambut baik niat Kartini untuk belajar di Eropa dan pemerintah menyatakan kesediaannya untuk memberikan bantuan uang sebesar 4.800 Gulden untuk mendukung niatnya tersebut. ${ }^{15}$ Akan tetapi Kartini tidak lagi antusias menerima balasan tersebut sebab ia akan segera menikah dengan Bupati Rembang yaitu RM Joyo Adiningrat.

Hal lain yang menjadi perhatian Kartini tentang ketidakadilan terhadap wanita adalah berkembang suburnya poligami. Kartini berpendapat bahwa poligami merupakan salah satu bentuk kesewenang-wenangan pria terhadap wanita. Kartini melihat, dan merasakan betapa besar penderitaan dan pengorbanan kehidupan wanita yang dimadu oleh suaminya. Hal inipun dilakukan oleh orang tuanya, abang-abangnya dan para raden mas yang lainnya di lingkungan Kabupaten Jepara dan kabupaten-kabupaten lainnya. Hal penting yang menjadi perhatian Kartini terhadap kasus poligami adalah adanya dorongan dari orang tua agar anaknya mendapat suami dari kaum bangsawan dengan tujuan untuk memperoleh kehormatan dan kemewahan.

Menurut Kartini, gadis-gadis tersebut tidak dapat dipersalahkan karena pada umumnya mereka merupakan anak-anak dari keluarga yang melarat yang terdiri dari petani dan buruh pabrik. Mereka berangan-angan mendapat kemewahan, kehormatan, dan kenikmatan duniawi lainnya. Dikawini oleh bangsawan merupakan anugerah yang membuka jalan bagi mereka untuk mobilitas sosial secara vertikal. Mereka akan menjadi putrid-putri kabupaten, kepangeranan, atau kesultanan yang bergelimang dengan kemewahan. ${ }^{16}$ Kartini melihat dan mencatat kejadian-kejadian tersebut dalam hati sanubarinya. Ia merasakan betapa getir nasibnya nanti apabila dirinya akan mengalami nasib seperti gadis-gadis tersebut.

\footnotetext{
${ }^{15}$ Sosroatmojo, op. cit., hlm. 43.

${ }^{16}$ Ibid., hlm. 33.
} 
Dalam suratnya kepada Stella Zeehandelaar tertanggal 25 Mei 1899, Kartini juga menuliskan kisahnya ketika mengalami masa pingitan sebagai berikut:: "When I reach the age of twelve, I was kept at home. I had to go into the box. I was locked up, and cut off from all communication with the outside world, toward which I might never turn again save at the side of bridegroom, a stranger, an unknown man whom my parents would choose for me, and to whom I should betrothed without my own knowledge..."17 Bagi Kartini masa-masa menjalani pingitan merupakan masa-masa kelam dalam perjalanan hidupnya, apalagi dia kemudian tahu bahwa orang tuanya telah mempersiapkan seorang laki-laki yang tak dikenalnya sebagai calon suaminya.

Kartini berpendirian bahwa calon-calon suami itu seharusnya telah terlebih dahulu dikenal oleh gadis-gadis yang akan diperistri, dan tidak disodorkan begitu saja sebagai calon suami hasil pilihan orang tuanya. Ini merupakan sebuah tragedi yang amat meletihkan dan memupuskan roh dan harapannya sebagai gadis modern yang berkemauan keras untuk melawan belenggu tradisi dan konstruk budaya Jawa yang feodalistik, dan monoton. Namun konstruk budaya yang demikian kuat melahirkan ketidakdilan gender itu nyatanya masih kuat mengakar di dalam masyarakat. Jalan untuk merubah kondisi wanita saat itu tidak lain melalui pendidikan. Hal ini diungkapkan oleh Kartini dalam suratnya kepada Mevrouw Van Kol pada bulan Agustus 1901.

Kartini yang berkorespodensi langsung dengan tokoh feminis Belanda Stella Zeehandelaar secara tidak langsung telah terpengaruh oleh konsep-konsep feminisme liberal. Hal ini dapat dilihat dari program utamanya yaitu membebaskan perempuan dari kebutaan pendidikan atau pengetahuan dengan mendirikan sekolah khusus, agar hak perempuan untuk mengikuti pendidikan setara dengan hak pendidikan untuk laki-laki. Kepada Van Kol Kartini menulis, “...Our idea is open, as soon as we have the means, an institute for the daughter of native officials, where they will be fitted for practical life and will be taught as well the things which elevate the spirit, and ennoble the mind...."18

\footnotetext{
${ }^{17}$ Geertz, Hildred, op. cit., hlm. 32-33.

${ }^{18}$ Ibid., hlm. 115.
} 
Kartini menyadari bahwa untuk membuat bangsanya maju, khususnya kaum wanita, maka tidak bisa tidak adalah dengan jalan belajar dari dunia Barat. Peradaban Barat yang demikian gemilang menyilaukan semangat Kartini untuk belajar demi pembebasan dari kungkungan feodalisme budaya yang timpang itu.

\section{Nasionalisme Kartini}

Nasionalisme merupakan sebuah ekspresi emosional antara warga negara dengan tanah dimana tempat dia dilahirkan. Oleh karenanya gejala timbulnya nasionalisme merupakan suatu gejala yang wajar, dimana secara psikologis ada hubungan emosional yang signifikan antara warga negara dengan wilayah negaranya. Namun pengertian nasionalisme menemukan momentumnya pada awal abad ke-20 yaitu ketika pengertian nasionalisme ditempatkan sebagai antithesis dari imperialisme dan kolonialisme.

Nasionalisme dapat digolongkan dalam dua arti. Pertama dalam arti negatif yang diartikan sebagai sikap keterlaluan, sempit, congkak dan sombong. Dalam hal ini, imperialisme-kolonialisme merupakan manifestasi dari pengertian tersebut. Kedua nasionalisme dalam pengertian positif sebagai ekspresi dari sikap untuk mempertahankan kemerdekaan dan harga diri bangsa dan sekaligus menghormati bangsa lain. $^{19}$ Pengertian kedua merupakan sikap positif seorang warga negara yang memiliki komitmen dan tanggung jawab terhadap keadaan bangsanya. Dalam pengertian yang positif, nasionalisme dapat diartikan sebagai suatu paham yang meletakkan kesetiaan tertinggi individu atau sekelompok individu kepada negara. Dalam kaitan tersebut, Ruslan Abdulgani mengemukakan bahwa nasionalisme dianggap sebagai sebuah ajaran, ideologi, kepercayaan, keyakinan, bahkan dianggap semacam agama baru. ${ }^{20}$

Nasionalisme Kartini dapat dilacak dari pemikirannya yang terdapat dalam surat-suratnya. Nasionalisme Kartini merupakan refleksi sosial yang kritis dari seorang wanita Indonesia yang didasarkan pada religieusiteit, wijsheid en schoonheid (ketuhanan, kebijaksanaan dan keindahan) ditambah dengan humanitarianisme (kemanusiaan) dan nasionalisme. Nasionalisme yang tampak

${ }^{19}$ Nursarastriya, Haris., “Nasionalisme Kartini dan Teori Tentang Nasionalisme”, Kritis: Jurnal UKSW No. 4/Th. X April -Juni 1997. hlm. 7.

${ }^{20}$ Ibid., hlm. 8 
dalam pandangan Kartini dapat dikategorikan sebagai sebagai nasionalisme universal dalam arti gagasan-gagasan yang diungkapkan mengandung nilai-nilai universal, seperti pendidikan, persamaan derajat, dan solidaritas sosial. ${ }^{21}$

Dalam suratnya kepada Stella Zeehandelaar pada tanggal 12 Januari 1900, Kartini mengutip pandangan ayahnya dalam sebuah nota yang dikirimkan kepada pemerintah Hindia Belanda sebagai berikut, "Father says in his note that the government can't set the rice upon the table for every Javanese, and see that he partakes of it. But it can give him the means by which he can reach the place where he can find the food. The means is education. When the government provides a means of education for people, it is as though it placed torches in their hands which enabled them to find the good road that leads to the place where the rice is served. From it you will learn something of the present condition of the people. ... Father wishes to do everything that he can to help the people and needless to say, I am on his side”.22 Kartini memang selalu mengungkapkan gagasan pentingnya pendidikan sebagai jalan untuk meningkatkan derajat bangsanya.

Disamping itu Kartini juga mengingatkan pentingnya persatuan bagi bangsa Indonesia serta mengajak untuk menggalang persatuan diantara kalangan muda Indonesia baik pria maupun wanita. Hal ini terungkap dalam suratnya kepada kepada Ny. Abendanon pada tanggal 30 September 1901. “The young guard, regardless of sex, should band themselves together. We can each of us do something unaided, towards the uplifting and civilizing of our people, but if we were united our strength would be multiplied many times. By working together we could gather a goodly store of fruit. In union there is strength , and power. ${ }^{23}$

Sementara itu sisi humanitarianisme yang melekat dari diri Kartini tampak dalam ungkapannya dimana ia ingin dipandang sebagai individu yang sama dengan orang lain. Kartini merasa tidak berbeda dengan rakyat biasa yang sama-sama hidup dibawah penjajahan. Bahkan kartini ingin dipanggil Kartini saja, tanpa ditambah dengang embel-embel Raden Adjeng. Hal ini terungkap dalam suratnya kepada Stella Zeehandelaar pada tanggal 17 Mei 1902. Dalam suratnya tersebut, Kartini menulis, “... For the first time, my name would come out openly in

\footnotetext{
21 Ibid., hlm. 13

${ }^{22}$ Geertz, Hildred, op. cit., hlm.57.

${ }^{23}$ Ibid., hlm. 119-120.
} 
connection with my people. I am proud of that, Stella to be named in the same breath with my people. ${ }^{24}$ Kartini tidak mau dianggap jauh di atas orang lain, lebihlebih di atas insan yang sering disebut dengan rakyat jelata. Barangkali, ini merupakan dampak dari perkenalannya dengan Stella Zeehandelaar melalui korespodensinya. Seperti diketahui Stella Zeehandelaar merupakan sosok gadis yang demokratis karena berada dilingkungan masyarakat Barat yang demokratis, disamping ia merupakan anak orang biasa. ${ }^{25}$

Humanitarianisme Kartini merupakan refleksi kritis dari stratifikasi sosial yang hierakhis akibat konstruk budaya yang feodalistik. Gagasan ini merupakan embrio dari munculnya ide persamaan derajat atau yang dikenal dengan emansipasi dimana wanita sudah selayaknya ditempatkan pada proporsi yang semestinya. Pada sisi yang lain pemikiran tersebut juga mencerminkan adanya solidaritas sosial antara bangsa-bangsa yang sedang dijajah oleh bangsa asing. Apalah artinya memiliki darah bangsawan, dihormati, hidup mewah dan lain sebagainya, apabila ia juga sama-sama berada dibawah penguasaan bangsa lain. Arti dari semua itu adalah sebuah realitas bahwa bangsawan dan rakyat jelata berada dalam posisi yang sama, yaitu sama-sama dikuasai bangsa asing. ${ }^{26}$

Kartini sadar bahwa untuk mencapai cita-citanya tentang persatuan dan persamaan derajat manusia tersebut diperlukan perjuangan yang keras melalui pendidikan. Oleh karenanya minat Kartini dalam masalah pendidikan demikian besarnya. Keterbelakangan yang dihadapi bangsa Indonesia pada saat itu disebabkan oleh ketidaktahuan rakyat tentang cara mengatasi segala kesulitan yang dihadapinya seperti soal pangan, kesehatan, ataupun pendidikan bagi anak-anak.

\section{E. Simpulan}

Dari uraian di atas maka dapat kita ambil kesimpulan bahwa perjuangan Kartini memiliki dimensi yang amat luas. Kartini yang merupakan intelektual produk Politik Etis pada awal abad ke-19 telah sejak lama memperjuangkan

${ }^{24}$ Ibid., hlm. 169.

${ }^{25}$ Stella Zeehadelaar merupakan anak seorang buruh pabrik gelas di Belanda. Hubung-an Kartini dengannya sebatas melalui surat dan mereka belum pernah bertemu muka secara langsung. Kartini mengenal namanya melalui advertensi. Lihat Sosroatmojo, op.. cit.

${ }^{26}$ Sosroatmojo, op. cit., hlm. 17 
kesetaraan gender yang dikenal dengan perjuangan emansipasi. Refleksi kritis Kartini tentang keadaan kaum wanita pada zamannya merupakan embrio tumbuhnya nasionalisme meskipun sifatnya masih samar.

Menurut Kartini dalam surat-suratnya, keadaan wanita Indonesia pada zaman tersebut sangat memprihatinkan karena terbelenggu oleh hukum adat yang sangat bias terhadap jender. Pada zaman Kartini wanita merupakan makhluk inferior bila dibandingkan pria. Mereka tidak diperkenankan untuk tamil dalam kegitan-kegiatan publik. Mereka juga tidak mendapat pendidikan secara layak. Di samping itu adanya kawin paksa merupakan sebuah pemberangusan terhadap kebebasan gadis-gadis untuk menentukan sendiri calon suaminya. Kartini juga mengkritisi maraknya poligami yang dilakukan oleh para bangsawan Jawa pada masa tersebut. Menurut Kartini ini semua merupakan sebuah konstruk budaya yang sangat tidak adil. Sayangnya Kartini sendiri tidak berdaya untuk menghadapi semua keadaan tersebut. Akhirnya Kartini harus memendam keinginannya untuk melanjutkan studinya ke Eropa, menjalani masa pingitan, dan harus kawin dengan laki-laki yang merupakan pilihan orang tuanya. Inilah dilemma perjuangan Kartini, dimana dia harus mengalahkan komitmen dan idealismenya demi menjaga keharmonisan dengan ayahnya.

Sementara itu pemikiran Kartini tentang nasionalisme dapat kita lihat dari idenya untuk meningkatkan derajat bangsa, solidaritas sosial dan persatuan diantara kaum muda. Menurut Kartini jalan yang harus ditempuh untuk mengatasi persoalan tersebut adalah dengan pendidikan. Kartini menyadari bahwa kemiskinan, keterbelakangan, kebodohan dan lain-lain berakar dari ketidaktahuan masyarakat tentang cara menghadapinya. Mereka tidak tahu harus berbuat apa untuk meningkatkan derajat hidupnya. Oleh karenanya pendidikan mutlak dibutuhkan untuk membuka cakrawala pemikiran bangsa ini dan sekaligus memberdayakan rakyat untuk kesejahteraan dan kemakmurannya sendiri. Oleh karenanya Kartini kemudian sangat antusias mendirikan sekolah khususnya sekolah wanita. 


\section{Daftar Pustaka}

Awuy, Tomy F., (1995), Wacana Tragedi dan Dekonstruksi Kebudayaan, Yogyakarta: Jentera Wacana Publika.

Fakih, Mansour, (2004), Analisis Gender \& Transformasi Sosial, Yogyakarta: PT Pustaka Pelajar.

Geertz, Hildred (ed.) (1964), Letters of A Javanese Princess: Raden Adjeng Kartini,.(ab. Agnes Louise Symmers) New York: Norton Company.

Kuntowijoyo, (2003), Metodologi Sejarah, Yogyakarta: Tiara Wacana.

Muttaqin, Farid., “Sejarah Gerakan Perempuan yang Bias Jender”, Kompas Edisi 28 Juni 2004.

Nursarastriya, Haris., "Nasionalisme Kartini dan Teori Tentang Nasionalisme”, Kritis: Jurnal UKSW No. 4/Th. X April -Juni 1997.

Poesponegoro, Marwati Djoened \& Notosusanto, Nugoho., (1993), Sejarah Nasional Indonesia V, Jakarta: PT Balai Pustaka.

Sasroatmojo, Suryanto., (2005), Tragedi Kartini, Yogyakarta: Penerbit Narasi.

Wikipedia, www.wikipedia.org/wiki/Raden_Adjeng_Kartini. didownload tanggal 12 Februari 2007. 